\title{
The Resurgence of Policy Practice in Social Work
}

\author{
Richard Hoefer ${ }^{1}$
}

Published online: 11 November 2020

(C) Springer Nature Switzerland AG 2020

This issue marks the end of the first volume of The Journal of Policy Practice and Research. While I could wax poetic on this, I believe that there is a larger context that is important.

As a field, social work's emphasis on policy practice is being renewed. Many currents are coming together to create a formidable river. Influencing Social Policy, a sponsor of the journal, has been in existence for some time now and supports the relevance of social policy in the CSWE curriculum well. Sunny Harris Rome, the current President of the group works tirelessly with the strong board of the organization to support all faculty in teaching and researching social policy.

The wonderful colleagues behind Macro Matters, known as The Special Commission to Advance Macro Practice in Social Work, have created videos (see for example, https://www.youtube.com/watch?v=Qmsg27L6K6Q)and the CSWE-sponsored Specialized Practice Curricular Guide for Macro Social Work Practice that looks at how to understand and teach all three types of macro practice, which includes administration, community, and policy practice. The curriculum guide is available for free download at https://www.cswe.org/getattachment/Education-Resources/2015Curricular-Guides/2015-Macro-Guide-Web-Version.pdf.aspx).

Other organizations have supported the attention being paid to social policy, including ACOSA, (the Association for Community Organization and Social Action), and the National Association of Social Work (NASW). We are building on our own strengths to improve our understanding of how to conduct policy practice using the tools of research. This is leading to increased efforts to study the topics that long have been integral to the social work professional and educational communities.

These topics have been increasingly urgent due to the influence of Donald Trump and the years of his presidency for making painfully obvious to everyone who cares to look, the importance of social policy for creating a more equitable, diverse, and inclusive society. The problem is that the Trump presidency has show what happens when the national government works to erase the gains that have been made in the past.

Richard Hoefer

rhoefer@uta.edu

1 School of Social Work, University of Texas at Arlington, Box 19129, Arlington, TX 76019, USA 
The entire apparatus of the Federal government has been subverted to enrich the few and create intentional hardship on the many. It is a lesson teaching why we must never assume that benefits and progress once made are permanent.

Many states and localities have fallen under the same ideological brand as President Trump and have replicated the process of dismantling positive policy. Governors and state legislatures have refused to implement the Affordable Care Act. State Attorneys General have signed on to court cases to declare the Affordable Care Act unconstitutional. Many states use their governments for attacking or refusing to enforce national mandates preserving voting rights. Environmental standards are often ignored in the interest of business interests that fund elections and political interest groups. Movements to ensure that other policies and laws working for a more just society are denounced and undone by lack of implementation at all levels.

The Federal judiciary, once seen as the best protector of laws and regulations working towards a more just society have become another casualty of Senator Mitch McConnell and the Republican-controlled Senate who often ignored the need to confirm qualified nominees during President Obama's terms of office so that a future Republican President could appoint a large number of conservative judges and justices. Most egregiously, Sen. McConnell refused for months to schedule hearings on moderate Judge Garland Merrick (a nominee by President Obama to replace conservative Justice Antonin Scalia) but rushed through the confirmation process to appoint a conservative Judge Amy Coney Barrett within a few weeks of her nomination and just days before the 2020 elections.

As I write this, the results of many races, including the Presidency, are unknown. I hope they will be agreed on by the time this issue goes to press.

The Journal of Policy Practice and Research has the mission to add to all arenas of social welfare policy, and closely related fields. We have had an exciting first year, attracting an increasing number of manuscripts as the year progressed. A quick review of the articles shows a wide variety of theoretical and conceptual underpinnings as well as methodological approaches. I could not be more pleased that we have published manuscripts on topics such as street-level bureaucrats and intersectional policy logic, critical policy analysis of Medicare for older adult mental health in Latin/x and African Americans; multiple streams, and more. The manuscripts in this issue continue with what I hope to be the hallmark of the journal - a careful research approach to vital issues of teaching of, and conducting, policy practice, as well as deep analyses of social welfare policies of all kinds.

Starting a new journal from scratch is a challenging endeavor. The staff at Springer, especially Teresa Krause, have been wonderful. Reviewers have rallied to the cause, providing quick and useful reviews for manuscripts. I rely heavily on them all. Finally, the Journal would not exist without the submission of the manuscripts. To everyone, I extend a deep sense of gratitude and I look forward to great things to come. 